Behind the Bamboo Curtain 
James G. Hershberg

series editor

\section{Brothers in Arms}

The Rise and Fall of the Sino-Soviet Alliance, 1945-1963

Edited by Odd Arne Westad

\section{Economic Cold War}

America's Embargo against

China and the Sino-Soviet

Alliance, 1949-1963

Shu Guang Zhang

\section{Confronting Vietnam}

Soviet Policy toward the

Indochina Conflict, 1954-1963

Ilya V. Gaiduk

\section{Kim Il Sung in the Krushchev Era}

Soviet-DPRK Relations and the Roots of North Korean Despotism, 1953-1964

Balázs Szalontai

\section{Failed Illusions}

Moscow, Washington, Budapest and the 1956 Hungarian Revolt

Charles Gati 


\title{
Behind the Bamboo Curtain
}

\author{
China, Vietnam, and the \\ World beyond Asia
}

Edited by Priscilla Roberts

Woodrow Wilson Center Press

Washington, D.C.

Stanford University Press

Stanford, California 
EDITORIAL OFFICES

Woodrow Wilson Center Press

Woodrow Wilson International Center for Scholars

One Woodrow Wilson Plaza

1300 Pennsylvania Avenue, N.W.

Washington, DC 20004-3027

Telephone: 202-691-4010

www.wilsoncenter.org

ORDER FROM

Stanford University Press

Chicago Distribution Center

11030 South Langley Avenue

Chicago, IL 60628

Telephone: 1-800-621-2736

(C) 2006 by Priscilla Roberts

All rights reserved

$2 \begin{array}{llllllll}2 & 6 & 8 & 9 & 7 & 5 & 3 & 1\end{array}$

Library of Congress Cataloging-in-Publication Data

Behind the bamboo curtain : China, Vietnam, and the world beyond Asia / edited by

Priscilla Roberts.

p. cm. - (Cold War International History Project series)

Includes index.

ISBN-13: 978-0-8047-5502-3 (cloth : alk. paper)

ISBN-10: 0-8047-5502-7 (cloth : alk. paper)

1. China--Foreign relations-Vietnam (Democratic Republic) 2. Vietnam (Democratic

Republic)-Foreign relations-China. 3. Vietnam War, 1961-1975-Diplomatic history.

4. China-Foreign relations-1949-1976. 5. Vietnam-Foreign relations-20th century.

I. Roberts, Priscilla Mary. II. Series.

DS740.5.V5B44 2006

$959.704^{\prime} 32-\mathrm{dc} 22$

2006015450 
The Woodrow Wilson International Center for Scholars, established by Congress in 1968 and headquartered in Washington, D.C., is a living, national memorial to President Wilson.

The Center is a nonpartisan institution of advanced research, supported by public and private funds, engaged in the study of national and world affairs. The Center establishes and maintains a neutral forum for free, open, and informed dialogue.

The Center's mission is to commemorate the ideals and concerns of Woodrow Wilson by providing a link between the world of ideas and policy, by bringing a broad spectrum of individuals together to discuss important public policy issues, by serving to bridge cultures and viewpoints, and by seeking to find common ground.

Conclusions or opinions expressed in Center publications and programs are those of the authors and speakers and do not necessarily reflect the views of the Center staff, fellows, trustees, advisory groups, or any individuals or organizations that provide financial support to the Center.

The Center is the publisher of The Wilson Quarterly and home of Woodrow Wilson Center Press, dialogue radio and television, and the monthly newsletter "Centerpoint." For more information about the Center's activities and publications, please visit us on the Web at www.wilsoncenter.org.

Lee H. Hamilton, President and Director

Board of Trustees

Joseph B. Gildenhorn, Chair

David A. Metzner, Vice Chair

Public members: James H. Billington, Librarian of Congress; G. Wayne Clough, Secretary of the Smithsonian Institution; Bruce Cole, Chairman, National Endowment for the Humanities; Michael O. Leavitt, Secretary of Health and Human Services; Condoleezza Rice, Secretary of State; Margaret Spellings, Secretary of Education; Allen Weinstein, Archivist of the United States; Mark R. Dybul, designated appointee of the President from within the federal government

Private citizen members: Robin Cook, Donald E. Garcia, Bruce S. Gelb, Sander R. Gerber, Charles L. Glazer, Susan Hutchison, Ignacio E. Sanchez 
The Cold War International History Project was established by the Woodrow Wilson International Center for Scholars in 1991. The project supports the full and prompt release of historical materials by governments on all sides of the Cold War and seeks to disseminate new information and perspectives on Cold War history emerging from previously inaccessible sources on the "the other side"--the former Communist world--through publications, fellowships, and scholarly meetings and conferences. The project publishes the Cold War International History Project Bulletin and a working paper series, and maintains a website, http://www.cwihp.org.

At the Woodrow Wilson Center, the project is part of the History and Public Policy Program, directed by Christian F. Ostermann. The project is overseen by an advisory committee that is chaired by William Taubman (Amherst College), and includes Michael Beschloss; James H. Billington (Librarian of Congress); Warren I. Cohen (University of Maryland at Baltimore); John Lewis Gaddis (Yale University); James G. Hershberg (George Washington University); Samuel F. Wells Jr. (Woodrow Wilson Center); and Sharon Wolchik (George Washington University).

The Cold War International History Project is supported by the Henry Luce Foundation (New York, NY), the Korea Foundation (Seoul, South Korea), the John D. and Catherine T. MacArthur Foundation (Chicago, IL), the Ratiu Family Foundation (London, UK), and the Smith Richardson Foundation (Westport, CT). 